Mexico and Mexicans in the Making of the United States 
History, Culture, and Society Series

Center for Mexican American Studies (CMAS)

University of Texas at Austin 


\section{Mexico and Mexicans in the Making of the United States}

EDITED BY JOHN TUTINO

University of Texas Press $\mathbf{v}$ Austin 
Portions of Chapter 5 adapted by permission of the publisher from Borderline Americans: Racial Division and Labor War in the Arizona Borderlands by Katherine Benton-Cohen, pp. 24, 3I, 33, 45, 38-4I, 5I-6I, 82, 86, 87, 95, 98, 100, 228-230, 239240, 247, 253, 255-256, 26I-262, 269, Cambridge, Mass.: Harvard University Press, copyright $\odot 2009$ by the President and Fellows of Harvard College.

Copyright $\odot 2012$ by the University of Texas Press All rights reserved

Printed in the United States of America

First edition, 2012

Requests for permission to reproduce material from this work should be sent to: Permissions

University of Texas Press

P.O. Box 7819

Austin, TX $78713-7819$

www.utexas.edu/utpress/about/bpermission.html

(a) The paper used in this book meets the minimum requirements of ANSI/NISO Z39.48-r992 (Rr997) (Permanence of Paper).

\section{Library of Congress Cataloging-in-Publication Data}

Mexico and Mexicans in the making of the United States / edited by John Tutino.

p. $\quad \mathrm{cm} .-$ (History, culture, and society series)

Includes bibliographical references and index.

ISBN 978-0-292-73718-I (cloth : alk. paper) - ISBN 978-o-292-73719-8 (e-book)

I. Mexican Americans-History. 2. Mexicans-United States-History.

3. United States-Foreign relations-Mexico. 4. Mexico-Foreign relations-

United States. I. Tutino, John, I947-

EI84.M5M536 2012

$973^{\prime} .046872-d_{c} 23$ 
For the extended and expanding

Campos and Delgado families of

New Braunfels, Kyle, and Austin, Texas:

they live the challenges and triumphs engaged here.

And for all the teachers in my

NEH Summer Seminars:

they taught me that Mexican and U.S. bistory are one. 
THIS PAGE INTENTIONALLY LEFT BLANK 